\title{
FAKTOR-FAKTOR UNTUK PENINGKATAN KEMANDIRIAN PETANI DALAM PENGELOLAAN HUTAN RAKYAT: STUDI KASUS DI DESA RANGGANG, KABUPATEN TANAH LAUT, KALIMANTAN SELATAN (Factors Improving Self-reliance of Farmers in Community Forest Management: Case Study in Ranggang Village, Tanab Laut Regency, South Kalimantan)
}

\author{
Idin Saepudin Ruhimat \\ Balai Penelitian Teknologi Agroforestry, Jalan Ciamis Banjar Km 4, Ciamis, Indonesia \\ e-mail: idintea@yahoo.co.id
}

Diterima 6 Juni 2014, direvisi 17 Juli 2014, disetujui 18 Agustus 2014

\begin{abstract}
Lack of farmers' self-reliance is one of inbibiting factors of community forest management in Ranggang village. This study aims to analyze the influencing factors to farmers' self-reliance and to formulate possible improvement efforts. This research was conducted in Ranggang village, using survey method with explanatory approach. The analytical method used is Structural Equation Modeling (SEM) analysis with SmartPLs 2.0 M3 program. Results showed that the farmers ability and dynamic level directly affect to farmers' selfreliance, while socio-cultural environment, farmers characteristics, external support, extention performance, and innovation availability are all have indirect effects. This study concluded that the farmers' self-reliance in community forest management in Ranggang village is low due to lack of farmers ability and dynamism in community forest management. Therefore, improvement can be done by increasing farmers ability and dynamism. National and regional governments are advised to strengthen the institutions of education, training and forestry extension, increased capacity of forestry extension workers and availability of technological innovation covering both technical and nontechnical.
\end{abstract}

Keywords: Farmers' self-reliance, community forest management, structural analysis.

\begin{abstract}
ABSTRAK
Rendahnya tingkat kemandirian petani merupakan salah satu faktor penghambat keberhasilan petani dalam pengelolaan hutan rakyat di Desa Ranggang. Penelitian ini bertujuan untuk menganalisis faktor-faktor yang berpengaruh terhadap tingkat kemandirian petani dan merumuskan usaha peningkatan kemandirian petani dalam pengelolaan hutan rakyat di Desa Ranggang. Penelitian dilaksanakan di Desa Ranggang, Kabupaten Tanah Laut, Kalsel menggunakan metode survei yang bersifat eksplanasi. Data dianalisis menggunakan pendekatan Structural Equation Modeling (SEM) dengan program SmartPLs 2.0 M3. Hasil penelitian menunjukkan bahwa tingkat kemampuan dan kedinamisan petani dalam pengelolaan hutan rakyat merupakan faktor yang berpengaruh langsung terhadap tingkat kemandirian petani, sedangkan lingkungan sosial budaya, karakteristik petani, dukungan pihak luar, kinerja penyuluhan dan tingkat ketersediaan inovasi merupakan faktor yang berpengaruh tidak langsung. Dari penelitian ini diperoleh kesimpulan bahwa tingkat kemandirian petani dalam pengelolaan hutan rakyat di Desa Ranggang masih rendah, hal ini disebabkan oleh rendahnya kemampuan dan kedinamisan petani. Oleh karena itu, peningkatan kemandirian petani dapat dilakukan melalui peningkatan kemampuan dan kedinamisan petani dalam pengelolaan hutan rakyat. Pemerintah pusat dan daerah disarankan untuk melakukan penguatan kelembagaan pendidikan, pelatihan dan penyuluhan kehutanan di daerah, peningkatan kapasitas penyuluh kehutanan dan peningkatan ketersediaan inovasi teknologi yang mencakup teknis maupun non teknis.
\end{abstract}

Kata kunci: Kemandirian petani, pengelolaan hutan rakyat, analisis struktural.

\section{PENDAHULUAN}

Hutan rakyat memiliki peran penting dalam kehidupan masyarakat Indonesia, baik peran ekonomi, ekologi, sosial maupun budaya. Mindawati et al. (2006) dan Zulkarnain (2008) mengemukakan hutan rakyat berperan dalam meningkatkan pendapatan masyarakat, memperbaiki kondisi lahan dan lingkungan serta memperluas kesempatan kerja. Keberhasilan usahatani hutan rakyat di Indonesia akan berdampak positif terhadap pembangunan nasional Indonesia seperti pening- 
katan kesejahteraan masyarakat khususnya petani, perbaikan lingkungan hidup dan peningkatan keamanan hutan (Mindawati et al., 2006).

Tinggi-rendahnya tingkat keberhasilan petani dalam pengelolaan hutan rakyat merupakan salah satu aspek yang berpengaruh terhadap optimalisasi peran hutan rakyat dalam kehidupan masyarakat Indonesia, termasuk Provinsi Kalimantan Selatan. Zulkarnain (2008) menyebutkan bahwa keberhasilan dalam pengelolaan hutan rakyat merupakan salah satu aspek yang memiliki peranan penting dalam meningkatkan peran hutan rakyat dalam aspek ekonomi, sosial, ekologi dan budaya. Menurut Ruhimat (2011), Ediningtyas (2007) dan Zulkarnain (2008) tingkat keberhasilan petani dalam pengelolaan hutan rakyat di beberapa daerah di Indonesia termasuk di Provinsi Kalimantan Selatan masih berada pada kategori rendah.

Menurut Ruhimat (2011) salah satu penyebabnya adalah rendahnya tingkat kemandirian petani dalam pengelolaan hutan rakyat, baik kemandirian teknis maupun manajerial. Menurut Ediningtyas (2007) belum optimalnya pengelolaan hutan rakyat di Indonesia adalah rendahnya tingkat kemandirian petani dalam pengelolaan hutan rakyat, baik kemandirian manajerial, material maupun intelektual. Da-pat disimpulkan bahwa salah satu penyebab utama ketidakoptimalan petani dalam pengelolaan hutan rakyat adalah rendahnya tingkat kemandirian petani.

Menurut Ruhimat (2010) seluruh luasan hutan rakyat di Desa Ranggang, Kalimantan Selatan dibangun dan dibiayai oleh pemerintah melalui berbagai program seperti Gerakan Nasional Rehabilitasi Hutan dan Lahan (GNRHL), program pembangunan hutan rakyat kemitraan oleh Balai Pengelolaan Daerah Aliran Sungai Barito (BPDAS Barito) dan program pengembangan dan pengayaan hutan rakyat dari Anggaran Pendapatan Belanja Daerah (APBD) kabupaten.

Penelitian yang dilakukan Ruhimat (2010) tidak menganalisis faktor-faktor yang berpengaruh terhadap rendahnya tingkat kemandirian petani dalam pengelolaan hutan rakyat di Desa Ranggang, padahal dengan mengetahui faktor-faktor yang berpengaruh terhadap kemandirian petani, maka dapat dirumuskan usaha peningkatan kemandirian petani dalam pengelolaan hutan rakyat di Desa Ranggang. Oleh karena itu, penelitian ini bertujuan untuk menganalisis faktor yang berpengaruh terhadap tingkat kemandirian dan merumuskan usaha peningkatan kemandirian petani dalam pengelolaan hutan rakyat di Desa Ranggang.

Hasil penelitian ini diharapkan menjadi bahan pertimbangan untuk stakeholders (pemerintah, LSM dan swasta) dalam upaya meningkatkan kemandirian petani dalam pengelolaan hutan rakyat di Desa Ranggang, Kalimantan Selatan.

\section{METODE PENELITIAN}

\section{A. Populasi dan Sampel Penelitian}

Penelitian ini dilakukan dengan metode survei yang bersifat eksplanasi yaitu menjelaskan gejala perilaku petani dan keterkaitan antar variabel penelitian (Indraningsih, 2013; Sumarlan et al., 2012). Penelitian dilaksanakan di Desa Ranggang, Kecamatan Takisung, Kabupaten Tanah Laut, Provinsi Kalimantan Selatan. Pemilihan Desa Ranggang sebagai lokasi penelitian dilakukan dengan penarikan sampel bertujuan (purposive) karena Desa Ranggang merupakan salah satu desa yang menjadi lokasi pengembangan hutan rakyat. Populasi dalam penelitian ini adalah seluruh kepala keluarga (KK) di Desa Ranggang yang memiliki hutan rakyat. Berdasarkan batasan tersebut, populasi dalam penelitian ini sebanyak $130 \mathrm{KK}$.

Pengambilan sampel penelitian menggunakan teknik penarikan sampel acak sederhana (simple random sampling) terhadap seluruh $\mathrm{KK}$ yang termasuk dalam populasi penelitian. Jumlah sampel penelitian adalah 98 orang, yang diperoleh dari hasil penghitungan sampel penelitian menggunakan rumus Solvin sebagai berikut (Mun'im, 2012; Wiyono, 2011; Riduan, 2007):

$$
\begin{aligned}
n & \frac{N}{1 N e^{2}} \\
\mathrm{n}= & \text { ukuran sampel } \\
\mathrm{N}= & \text { populasi } \\
\mathrm{e}= & \text { margin of error (pada penelitian ini ditetapkan } \\
& \quad 0,05 \text { dengan tingkat kepercayaan } 95 \% \text { ) }
\end{aligned}
$$

Wiyono (2011) menyebutkan jumlah sampel minimal untuk melakukan analisis SEM dengan program SmartPLs 2.0 M3 adalah 30 orang. Berdasarkan rumus Solvin maka jumlah sampel penelitian 98 orang telah memenuhi syarat dalam analisis SEM dengan menggunakan program SmartPls 2.0 M3. 


\section{B. Teknik Pengumpulan dan Analisis Data}

Data yang dikumpulkan dalam penelitian ini terdiri dari data sekunder dan data primer. Data sekunder diperoleh dari hasil studi pustaka dan studi dokumentasi yang memiliki keterkaitan dengan tema penelitian. Data primer diperoleh dari pengamatan langsung terhadap obyek penelitian dan survei menggunakan kuesioner bersifat tertutup. Format jawaban dalam kuesioner tertutup menggunakan skala Likert (Likert Summated Rating) dengan lima alternatif jawaban.

Data dianalisis dengan statistik deskriptif dan statistik inferensial. Analisis deskriptif dilakukan dengan menggunakan program Microsoft Excel 2007 sedangkan analisis inferensial dilakukan dengan analisis SEM menggunakan program SmartPLS 2.0 M3. Menurut Santoso (2012) analisis SEM adalah alat analisis statistik yang menggabungkan analisis faktor dan analisis regresi yang bertujuan untuk menganalisis model hubungan antara variabel dengan variabel/indikator yang tidak dapat dilakukan dengan alat analisis lainnya seperti uji-t, anova, korelasi atau regresi berganda.

\section{Variabel Penelitian}

Variabel penelitian yang digunakan dalam penelitian ini diperoleh dari hasil studi pustaka terhadap hasil penelitian terdahulu yang memiliki keterkaitan dengan tingkat kemandirian petani, di antaranya: Subagio (2008) mengemukakan bahwa kemandirian petani dalam berusa hatani sayuran dan padi di Provinsi Jawa Timur dipengaruhi secara nyata oleh karakteristik petani, ketersediaan inovasi, dukungan lingkungan sosial budaya, kapasitas petani dan kedinamisan usahatani; Anantanyu (2008) menyatakan bahwa kemampuan petani merupakan faktor penentu dalam mewujudkan kemandirian petani di Provinsi Jawa Tengah. Selain itu, Ediningtyas (2007) menyebutkan kemandirian petani dalam usahatani agroforestri program kemitraan petani dengan PT. Perhutani Unit III di Kecamatan Ciwidey, Kabupaten Bandung, Jawa Barat dipengaruhi oleh faktor dukungan dari luar petani, tingkat pendidikan dan pengalaman usahatani. Lebih lanjut menurut Mulyandari (2001) bahwa karakteristik petani dan kinerja penyuluhan berpengaruh nyata terhadap tingkat kemandirian petani dalam berusaha tani di Desa Ciherang, Bogor, Jawa Barat.

Berdasarkan hasil penelitian yang telah dilakukan Subagio (2008), Anantanyu (2008),
Ediningtyas (2007) dan Mulyandari (2001), maka variabel dalam penelitian ini merupakan gabungan variabel yang dihasilkan dari keempat penelitian tersebut, sehingga penelitian ini diharapkan memperoleh hasil yang lebih komprehensif dalam menganalisis faktor-faktor yang berpengaruh terhadap kemandirian petani. Adapun variabel tersebut terdiri dari variabel tingkat dukungan lingkungan sosial budaya $\left(\mathrm{X}_{1}\right)$, tingkat dukungan pihak luar $\left(\mathrm{X}_{2}\right)$, kinerja penyuluhan $\left(\mathrm{X}_{3}\right)$, karakteristik petani $\left(\mathrm{X}_{4}\right)$, tingkat kemampuan petani $\left(\mathrm{X}_{5}\right)$, tingkat kedinamisan petani $\left(\mathrm{X}_{6}\right)$, tingkat ketersediaan inovasi $\left(\mathrm{X}_{7}\right)$ dan tingkat kemandirian petani dalam pengelolaan hutan rakyat $(\mathrm{Y})$.

\section{HASIL DAN PEMBAHASAN}

\section{A. Gambaran Umum Desa Ranggang}

Secara administratif, Desa Ranggang merupakan salah satu dari 12 desa di Kecamatan Takisung, Kabupaten Tanah Laut, Provinsi Kalimantan Selatan dengan luas wilayah $11,3 \mathrm{~km}^{2}$ yang tersebar menjadi empat dusun dengan 12 Rukun Tetangga (RT). Sebelah utara berbatasan dengan Desa Ranggang Dalam, sebelah selatan berbatasan dengan Desa Banua Lawas dan Desa Banua Tengah, sebelah barat berbatasan dengan Desa Pagatan Besar dan Desa Gunung Makmur serta sebelah timur berbatasan dengan Desa Batilai (Anonim, 2010).

Jumlah penduduk Desa Ranggang sampai dengan tahun 2009 adalah sebanyak 2.506 jiwa dengan tingkat kerapatan penduduk per $\mathrm{km}^{2}$ sebanyak 222 penduduk yang tersebar dalam 658 KK. Mata pencaharian utama penduduk Desa Ranggang terdiri dari 70\% petani, $15 \%$ pedagang, $5 \%$ pembuat arang kayu, 2\% pegawai pemerintah atau karyawan swasta, $5 \%$ buruh dan $2 \%$ pekerjaan lainnya (Badan Pusat Statistik, 2009).

Sejak tahun 2003, pemerintah telah melaksanakan berbagai program pembangunan hutan rakyat di Desa Ranggang, di antaranya pembangunan hutan rakyat melalui program GNRHL, program Hutan Rakyat (HR) BPDAS Barito, dan program Hutan Rakyat APBD II. Rincian jenis program, tahun penanaman, luasan dan jenis tanaman dalam program pembangunan hutan rakyat di Desa Ranggang dapat dilihat pada Tabel 1.

Berdasarkan Tabel 1 dapat dilihat bahwa total luasan pembangunan hutan rakyat yang telah dila- 
kukan oleh masyarakat Desa Ranggang melalui program GNRHL, HR BPDAS dan HR APBD II adalah 265 ha dengan jenis tanaman pokok berupa tanaman mahoni, baik yang ditanam secara monokultur maupun tumpangsari dengan tanaman karet.

Potensi luasan hutan rakyat yang tersedia di Desa Ranggang adalah sekitar 400 ha dengan luasan yang telah ditanami sekitar 370 ha. Kegiatan budidaya hutan rakyat tersebut sebagian besar dilakukan oleh dua dari delapan kelompok tani yang ada di Desa Ranggang, yaitu Kelompok Tani Sido Maju di RT 6 dan Sinar Karya di RT 7 (Rohadi, 2012).

\section{B. Deskripsi Variabel Penelitian}

\section{Tingkat Kemandirian Petani}

Tingkat kemandirian petani dalam pengelolaan hutan rakyat di Desa Ranggang termasuk kategori rendah karena semua aspek kemandirian intelektual, material dan pembinaan memiliki nilai indeks 30,19 yang berada pada interval nilai 0-33,33 (Tabel2).

\section{Tingkat Kemampuan Petani}

Secara umum, kemampuan teknis dan sosial petani hutan rakyat di Desa Ranggang termasuk kategori sedang serta kemampuan manajerial termasuk kategori rendah sebagaimana diperlihatkan dalam Tabel 3 .

Tabel 1. Program pembangunan hutan rakyat di Desa Ranggang.

Table 1. People forest development program in Ranggang village.

\begin{tabular}{ccccc}
\hline No & $\begin{array}{c}\text { Tahun penanaman } \\
\text { (Years of planting) }\end{array}$ & $\begin{array}{c}\text { Nama program } \\
\text { (Name of program })\end{array}$ & $\begin{array}{c}\text { Luasan (Area) } \\
\text { (ha) }\end{array}$ & $\begin{array}{c}\text { Jenis } \\
(\text { Species })\end{array}$ \\
\hline 1 & 2003 & HR GNRHL & 25 & Mahoni \\
2 & 2004 & HR GNRHL & 15 & Mahoni \\
3 & 2005 & HR GNRHL & 25 & Mahoni \\
4 & 2007 & HR GNRHL & 25 & Mahoni, karet \\
5 & 2007 & HR BPDAS & 100 & Mahoni, karet \\
6 & 2007 & HR APBD II & 25 & Mahoni \\
7 & 2008 & HR GNRHL & 50 & Mahoni, karet \\
\hline
\end{tabular}

Sumber (Source): Ruhimat (2010)

Tabel 2. Tingkat kemandirian petani.

Table 2. Farmer's self reliance level.

\begin{tabular}{|c|c|c|c|c|}
\hline \multirow{2}{*}{$\begin{array}{l}\text { Variabel/indikator } \\
\text { (Variable/indicator) }\end{array}$} & \multirow{2}{*}{$\begin{array}{l}\text { Nilai indeks } \\
\text { (Indeks value) }\end{array}$} & \multicolumn{3}{|c|}{ Interval nilai indeks (Indeks value interval) } \\
\hline & & Tinggi $(H i g h)$ & Sedang (Moderate) & Rendah (Low) \\
\hline $\begin{array}{l}\text { Tingkat kemandirian petani (Degree of } \\
\text { independence of farmers) }\end{array}$ & 30,19 & $66,68-100$ & $33,34-66,67$ & $0-33,33$ \\
\hline $\begin{array}{l}\text { O Kemandirian intelektual } \\
\text { (Independence of intelectua) }\end{array}$ & 28,06 & $66,68-100$ & $33,34-66,67$ & $0-33,33$ \\
\hline $\begin{array}{l}\text { o Kemandirian material (Independence } \\
\text { of materiay) }\end{array}$ & 31,89 & $66,68-100$ & $33,34-66,67$ & $0-33,33$ \\
\hline $\begin{array}{l}\text { O Kemandirian pembinaan } \\
\text { (Independence of coacbing }\end{array}$ & 30,61 & $66,68-100$ & $33,34-66,67$ & $0-33,33$ \\
\hline
\end{tabular}

Tabel 3. Tingkat kemampuan petani.

Table 3. Farmer's abilities level.

\begin{tabular}{lcccc}
\hline \multicolumn{1}{c}{$\begin{array}{l}\text { Variabel/indikator } \\
\text { (Variable/indicator) }\end{array}$} & $\begin{array}{c}\text { Nilai indeks } \\
\text { (Indeks value) }\end{array}$ & \multicolumn{2}{c}{ Interval nilai indeks (Indeks value interval) } \\
\cline { 4 - 5 } $\begin{array}{l}\text { Tingkat kemampuan petani (Degree of } \\
\text { capacity of farmer) }\end{array}$ & 33,99 & $66,68-100$ & $33,34-66,67$ & $0-33,33$ \\
$\begin{array}{l}\text { O Kemampuan teknis (Technical acapacity) } \\
\text { O Kemampuan manajerial (Managerial }\end{array}$ & 35,20 & $66,68-100$ & $33,34-66,67$ & $0-33,33$ \\
$\begin{array}{l}\text { capacity) } \\
\text { O Kemampuan sosial (Social capacity) }\end{array}$ & 33,10 & $66,68-100$ & $33,34-66,67$ & $0-33,33$ \\
\hline
\end{tabular}




\section{Tingkat Kedinamisan Pengelolaan Hutan Rakyat}

Indikator penyusun variabel tingkat kedinamisan pengelolaan hutan rakyat di Desa Ranggang, Kalimantan Selatan (aspek kreativitas, inovasi dan daya saing) berada pada kategori rendah yaitu pada interval nilai 0-33,33 (Tabel 4).

\section{Tingkat Ketersediaan Inovasi}

Ketersediaan inovasi, baik inovasi teknis, manajerial maupun sosial dalam pengelolaan hutan rakyat merupakan salah satu faktor penting dalam keberlanjutan usahatani hutan rakyat di Desa Ranggang. Berdasarkan perhitungan secara deskriptif dengan menggunakan program Microsoft Excel 2007 diperoleh hasil tingkat ketersediaan inovasi dalam pengelolaan hutan rakyat di Desa Ranggang memiliki nilai indeks 21,53 sehingga berada pada kategori rendah sebagaimana terlihat dalam Tabel 5 .

\section{Tingkat Dukungan Karakteristik Petani}

Tingkat dukungan karakteritik petani disusun oleh tiga indikator yaitu tingkat pendidikan informal, pendidikan formal dan pengalaman usaha tani. Berdasarkan hasil perhitungan deskriptif terhadap variabel tingkat dukungan karakteristik petani beserta indikator penyusunnya maka diperoleh hasil indeks nilai 32,89 (kategori rendah), terdiri atas indeks nilai aspek tingkat pendidikan informal 32,02 (kategori rendah), aspek pendidikan formal 32,02 (kategori rendah) dan aspek pengalaman usaha tani 34,63 (kategori sedang) sebagaimana terlihat dalam Tabel 6.

\section{Tingkat Dukungan Lingkungan Sosial Budaya}

Dukungan lingkungan sosial budaya dalam meningkatkan kemandirian petani pada pengelolaan hutan rakyat di Desa Ranggang termasuk kategori sedang yaitu berada pada interval nilai 22,34-66,67. Kategori sedang ini diperkuat oleh nilai indeks dukungan tokoh masyarakat dan kearifan lokal yang berkategori sedang sebagaimana diperlihatkan pada Tabel 7.

\section{Tingkat Dukungan Pihak Luar}

Tingkat dukungan pihak luar dalam meningkatkan kemandirian petani pada pengelolaan hutan rakyat di Desa Ranggang pada kategori rendah sebagaimana ditunjukkan oleh rendahnya nilai indeks seluruh indikator penyusunnya yaitu dukungan pemerintah, swasta dan lembaga swadaya masyarakat (Tabel 8).

Tabel 4. Tingkat kedinamisan petani dalam pengelolaan hutan rakyat.

Table 4. Farmers dynamism level of community forests management.

\begin{tabular}{lcccc}
\hline \multicolumn{1}{c}{$\begin{array}{l}\text { Variabel/indikator } \\
\text { (Variable/ indicator) }\end{array}$} & $\begin{array}{c}\text { Nilai indeks } \\
\text { (Indeks value) }\end{array}$ & \multicolumn{2}{c}{ Interval nilai indeks (Indeks value interval) } \\
\cline { 3 - 5 } & 28,23 & $66,68-100$ & $33,34-66,67$ & $0-33,33$ \\
\hline $\begin{array}{l}\text { Tingkat kedinamisan pengelolaan hutan } \\
\text { rakyat (Degree of dynamic of community ofrest } \\
\text { management) }\end{array}$ & & & & \\
$\begin{array}{l}\text { O Tingkat kreativitas petani (Degree of } \\
\text { creativity of farmer) }\end{array}$ & 30,87 & $66,68-100$ & $33,34-66,67$ & $0-33,33$ \\
$\begin{array}{l}\text { O Tingkat keinovatifan petani (Degree of } \\
\text { innovation of firmers) }\end{array}$ & 27,81 & $66,68-100$ & $33,34-66,67$ & $0-33,33$ \\
O Tingkat daya saing (Degree of competitivenes.) & 26,02 & $66,68-100$ & $33,34-66,67$ & $0-33,33$ \\
\hline
\end{tabular}

Tabel 5. Tingkat ketersediaan inovasi.

Table 5. Innovation availability level.

\begin{tabular}{lcccc}
\hline \multicolumn{1}{c}{$\begin{array}{l}\text { Variabel/indikator } \\
\text { (Variable/ indicator) }\end{array}$} & Nilai indeks & \multicolumn{2}{c}{ Interval nilai indeks (Indeks value interval) } \\
\cline { 3 - 5 }$($ Indeks value) & Tinggi (High) & Sedang (Moderate) & Rendah (Low) \\
\hline $\begin{array}{l}\text { Tingkat ketersediaan inovasi (Degree of } \\
\text { innovation availability) }\end{array}$ & 21,53 & $66,68-100$ & $33,34-66,67$ & $0-33,33$ \\
O Sifat inovasi (Innovation characteristics) & & & & \\
O Bentuk inovasi (Innovation type) & 20,87 & $66,68-100$ & $33,34-66,67$ & $0-33,33$ \\
\hline
\end{tabular}


Tabel 6. Tingkat dukungan karakteritik petani.

Table 6. Farmer's characteristic supporting level.

\begin{tabular}{|c|c|c|c|c|c|}
\hline \multirow{2}{*}{\multicolumn{2}{|c|}{$\begin{array}{l}\text { Variabel/indikator } \\
\text { (Variable/indicator) }\end{array}$}} & \multirow{2}{*}{$\begin{array}{l}\text { Nilai indeks } \\
\text { (Indeks value) }\end{array}$} & \multicolumn{3}{|c|}{ Interval nilai indeks (Indeks value interval) } \\
\hline & & & Tinggi (High) & Sedang (Moderate) & Rendah (Low) \\
\hline & $\begin{array}{l}\text { kungan karakteristik petani (Farmers } \\
\text { acteristics supported) }\end{array}$ & 32,89 & $66,68-100$ & $33,34-66,67$ & $0-33,33$ \\
\hline & $\begin{array}{l}\text { Pendidikan informal (Informal education) } \\
\text { Pendidikan formal (Formal education) }\end{array}$ & 32,02 & $66,68-100$ & $33,34-66,67$ & $0-33,33$ \\
\hline & $\begin{array}{l}\text { Pengalaman usahatani (Farmer business } \\
\text { experience) }\end{array}$ & $\begin{array}{l}32,02 \\
34,63\end{array}$ & $\begin{array}{l}66,68-100 \\
66,68-100\end{array}$ & $\begin{array}{l}33,34-66,67 \\
33,34-66,67\end{array}$ & $\begin{array}{l}0-33,33 \\
0-33,33\end{array}$ \\
\hline
\end{tabular}

Tabel 7. Tingkat dukungan lingkungan sosial budaya.

Table 7. Social cultural environment supporting level.

\begin{tabular}{|c|c|c|c|c|}
\hline \multirow{2}{*}{$\begin{array}{l}\text { Variabel/Indikator } \\
\text { (Variable/Indicator) }\end{array}$} & \multirow{2}{*}{$\begin{array}{l}\text { Nilai Indeks } \\
\text { (Indeks value) }\end{array}$} & \multicolumn{3}{|c|}{$\begin{array}{c}\text { Interval nilai indeks (Indeks value } \\
\text { interval) }\end{array}$} \\
\hline & & $\begin{array}{l}\text { Tinggi } \\
\text { (High) }\end{array}$ & $\begin{array}{c}\text { Sedang } \\
\text { (Moderate) }\end{array}$ & $\begin{array}{c}\text { Rendah } \\
\text { (Low) }\end{array}$ \\
\hline $\begin{array}{l}\text { Tingkat dukungan lingkungan sosial budaya (Degree of social culture } \\
\text { and environment supporting) }\end{array}$ & 43,17 & $66,68-100$ & $33,34-66,67$ & $0-33,33$ \\
\hline o Dukungan tokoh masyarakat (Local key person supporting) & 57,14 & $66,68-100$ & $33,34-66,67$ & $0-33,33$ \\
\hline o Dukungan kelompok tani ((Farmer group supporting)) & 29,97 & $66,68-100$ & $33,34-66,67$ & $0-33,33$ \\
\hline - Dukungan kearifan lokal (Local knowledge supporting) & 55,61 & $66,68-100$ & $33,34-66,67$ & $0-33,33$ \\
\hline
\end{tabular}

Tabel 8. Tingkat dukungan pihak luar.

Table 8. External supporting level.

\begin{tabular}{lcccc}
\hline \multirow{2}{*}{$\begin{array}{c}\text { Variabel/Indikator } \\
\text { (Variable/Indicator) }\end{array}$} & Nilai indeks & \multicolumn{2}{c}{ Interval nilai indeks (Indeks value interval) } \\
\cline { 3 - 5 }$($ Indeks value) & Tinggi (High) & Sedang (Moderate) & Rendah (Low) \\
\hline Dukungan pihak luar (External supporting) & 31,38 & $66,68-100$ & $33,34-66,67$ & $0-33,33$ \\
O Dukungan swasta (Private supporting) & 33,16 & $66,68-100$ & $33,34-66,67$ & $0-33,33$ \\
O Dukungan pemerintah (Government supporting) & 33,03 & $66,68-100$ & $33,34-66,67$ & $0-33,33$ \\
O Dukungan LSM (NGO supporting) & & & & \\
& 27,93 & $66,68-100$ & $33,34-66,67$ & $0-33,33$ \\
\hline
\end{tabular}

Tabel 9. Tingkat kinerja penyuluhan.

Table 9. Extention performance level.

\begin{tabular}{lcccc}
\hline \multirow{2}{*}{$\begin{array}{l}\text { Variabel/Indikator } \\
\text { (Variable/Indicator) }\end{array}$} & Nilai indeks & \multicolumn{3}{c}{ Interval nilai indeks (Indeks value interval) } \\
\cline { 3 - 5 }$($ Indeks value) & Tinggi (High) & Sedang (Moderate) & Rendah (Low) \\
\hline Tingkat kinerja penyuluhan (Extention & 40,01 & $66,68-100$ & $33,34-66,67$ & $0-33,33$ \\
performance leve) & & & & \\
O Kesesuaian materi (Material suitability) & 32,78 & $66,68-100$ & $33,34-66,67$ & $0-33,33$ \\
O Kesesuaian metode (Method suitability) & 33,29 & $66,68-100$ & $33,34-66,67$ & $0-33,33$ \\
○ Kompetensi penyuluh (Extention competency) & 53,95 & $66,68-100$ & $33,34-66,67$ & $0-33,33$ \\
\hline
\end{tabular}

\section{Tingkat Kinerja Penyuluhan}

Tingkat kinerja penyuluhan dalam meningkatkan kemandirian petani pada pengelolaan hutan rakyat di Desa Ranggang memiliki nilai indeks antara 33,33-66,67 artinya tergolong sedang. Nilai indeks untuk indikator penyusun variabel kinerja penyuluhan adalah rendah untuk kesesuaian materi $(32,78)$, rendah untuk kesesuaian metode $(33,29)$ dan sedang untuk kompetensi penyuluh $(53,95)$ sebagaimana dapat dilihat pada Tabel 9. 


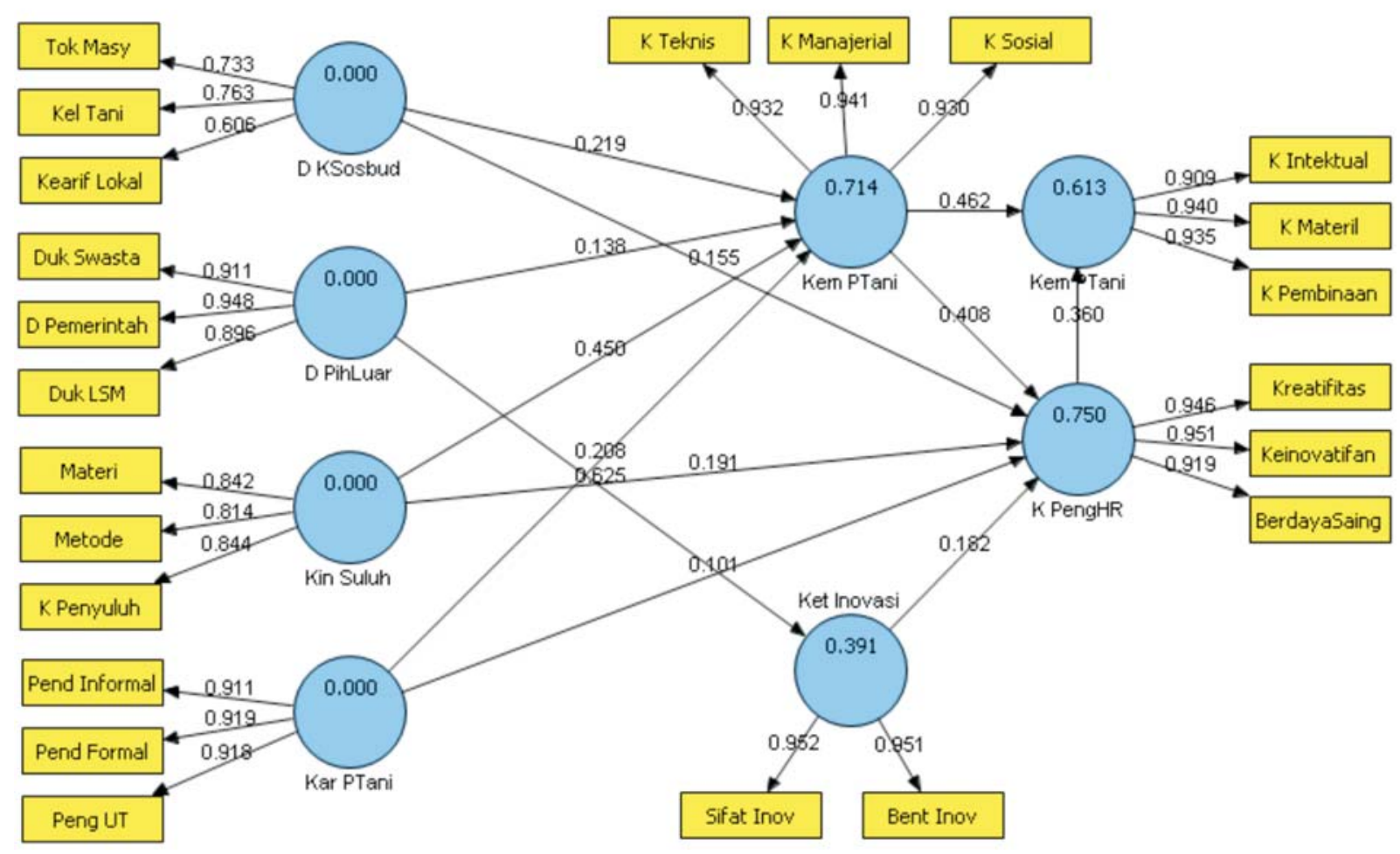

Gambar 1. Faktor-faktor yang berpengaruh terhadap kemandirian petani dalam pengelolaan hutan rakyat di Desa Ranggang.

Figure 1. Factors that effect to farmer's self reliance in community forests management in Ranggang village.

\section{Faktor yang Berpengaruh terhadap Tingkat Kemandirian Petani dalam Pengelolaan Hutan Rakyat}

Faktor-faktor yang berpengaruh terhadap tingkat kemandirian petani dalam pengelolaan hutan rakyat di Desa Ranggang diperoleh dari hasil analisis SEM menggunakan program SmartPls 2.0 M3. Berdasarkan hasil analisis tersebut, tingkat kemampuan petani dan tingkat kedinamisan pengelolaan hutan rakyat memiliki pengaruh nyata dan langsung terhadap tingkat kemandirian petani dalam pengelolaan hutan rakyat di Desa Ranggang, sedangkan faktor lainnya seperti tingkat dukungan karakteristik petani, tingkat dukungan pihak luar, tingkat kinerja penyuluhan dan tingkat ketersediaan inovasi berpengaruh tidak langsung. Faktorfaktor yang secara langsung maupun tidak langsung berpengaruh terhadap tingkat kemandirian petani dalam pengelolaan hutan rakyat di Desa Ranggang digambarkan seperti dalam Gambar 1.

Gambar 1 dapat diuraikan ke dalam faktor yang berpengaruh terhadap tingkat: 1) kemandirian petani; 2) kemampuan petani dan 3) kedinamisan petani dalam pengelolaan hutan rakyat.

\section{Faktor yang Berpengaruh terhadap Tingkat Kemandirian}

Gambar 1 menunjukkan bahwa faktor-faktor yang secara langsung mempengaruhi tingkat kemandirian petani dalam pengelolaan hutan rakyat terdiri dari faktor tingkat kemampuan petani dan faktor tingkat kedinamisan pengelolaan hutan rakyat. Hal ini berarti untuk meningkatkan kemandirian petani dalam pengelolaan hutan rakyat dapat dilakukan dengan meningkatkan kemampuan dan kedinamisan petani dalam pengelolaan hutan rakyat. Persamaan struktural pengaruh tingkat kemampuan dan tingkat kedinamisan petani terhadap tingkat kemandirian petani dalam pengelolaan hutan rakyat adalah sebagai berikut.

$\mathrm{Y}=0,462 \mathrm{X}_{5}+0,360 \mathrm{X}_{6}+\zeta$

$\mathrm{R}^{2}=0,6130$ atau $61,30 \%$

Keterangan (Remarks):

$\mathrm{Y}=$ tingkat kemandirian petani dalam pengelolaan hutan rakyat; $\mathrm{X}_{5}=$ tingkat kemampuan petani dalam pengelolaan hutan rakyat; $\mathrm{X}_{6}=$ tingkat kedinamisan pengelolaan hutan rakyat; $\zeta=$ faktor yang mempengaruhi tingkat kemandirian petani selain tingkat kemampuan petani dan kedinamisan petani; $\mathrm{R}^{2}=$ besaran pengaruh tingkat kemampuan petani dan kedinamisan petani terhadap kemandirian petani secara bersama-sama. 
Persamaan struktural tersebut memiliki pengertian bahwa tingkat kemandirian petani dalam pengelolaan hutan rakyat dipengaruhi oleh tingkat kemampuan petani dan tingkat kedinamisan pengelolaan hutan rakyat, baik secara masing-masing maupun secara bersamasama. Besaran pengaruh faktor tingkat kemampuan petani dan faktor tingkat kedinamisan pengelolaan hutan rakyat terhadap tingkat kemandirian petani secara bersama-sama adalah 0,6130 atau 61,30\%. Berdasarkan pendapat Sarwono (2012), angka 61,30\% berarti faktor tingkat kemampuan petani dan tingkat kedinamisan pengelolaan hutan rakyat berpengaruh kuat terhadap tingkat kemandirian petani dalam pengelolaan hutan rakyat.

Aspek penyusun faktor kemampuan petani yang berpotensi mempengaruhi kemandirian petani dalam pengelolaan hutan rakyat secara berurutan dari yang tinggi ke rendah adalah aspek kemampuan manajerial, aspek kemampuan teknis dan aspek kemampuan sosial (Gambar 1).

Aspek kemampuan manajerial merupakan aspek pertama dari faktor tingkat kemampuan petani yang paling berpengaruh terhadap tingkat kemandirian petani. Kemampuan manajerial meliputi kemampuan dalam merencanakan, mengatur, mengarahkan, dan mengevaluasi seluruh pengelolaan hutan rakyat yang akan mempengaruhi kemandirian petani dalam mengambil keputusan dalam pengelolaan hutan rakyat, baik yang berhubungan dengan kemadirian intelektual, kemandirian materil maupun kemandirian pembinaan. Hal ini sejalan dengan pendapat Suprayitno et al. (2011) di mana petani harus memiliki kemampuan manajerial untuk mengambil keputusan penting dalam mencapai keberhasilan usahatani seperti ketersediaan modal, pemasaran, teknis budidaya, pengelolaan sumberdaya dan kemitraan.

Aspek kemampuan teknis merupakan aspek kedua dari faktor tingkat kemampuan petani yang berpotensi besar mempengaruhi kemandirian petani dalam pengelolaan hutan rakyat di Desa Ranggang. Suprayitno (2011) menjelaskan kemampuan petani dalam mengetahui, menguasai, memahami, dan melaksanakan kaidah-kaidah teknis pengelolaan seperti pengetahuan dan keterampilan dalam budidaya tanaman akan meningkatkan kemandirian dan keberhasilan petani dalam pengelolaan hutan secara lestari.

Aspek ketiga dari faktor kemampuan petani dalam pengelolaan hutan rakyat di Desa Ranggang adalah aspek kemampuan sosial. Kemampuan sosial diartikan sebagai kemampuan petani hutan rakyat untuk berhubungan dengan pihak di luar dirinya seperti sesama petani, aparat pemerintahan (desa, kecamatan, kabupaten dan lainnya), pihak swasta, pihak lembaga swadaya masyarakat dan lainnya. Petani yang memiliki kemampuan sosial tinggi akan mampu memperoleh berbagai informasi seperti akses modal/kredit, pemasaran, ilmu pengetahuan dan teknologi terbaru dalam memecahkan permasalahan yang dihadapi pada pengelolaan hutan rakyat. Suprayitno (2011) menyebutkan seorang petani tidak akan mampu menghadapi seluruh permasalahan dalam pengelolaan usahatani sehingga perlu menjalin kerjasama/kemitraan dengan pihak lain. Kemampuan untuk menjalin kemitraan/kerjasama dalam memecahkan permasalahan pengelolaan hutan rakyat dengan pihak lain disebut sebagai kemampuan sosial.

Berdasarkan hasil analisis SEM (Gambar 1), tingkat kemandirian petani dalam pengelolaan hutan rakyat dipengaruhi juga oleh tingkat kedinamisan petani pengelolaan hutan rakyat. Terdapat tiga aspek dalam tingkat kedinamisan pengelolaan hutan rakyat yang berpengaruh terhadap tingkat kemandirian petani yaitu inovatif, kreativitas, dan daya saing dalam usahatani hutan rakyat. Tingginya tingkat inovatif petani dalam usahatani akan mendorong petani untuk selalu mencari inovasi dan informasi baru yang relevan dengan bidang usahataninya (Subagio, 2008), sehingga petani hutan rakyat di Desa Ranggang akan memiliki kemampuan untuk meningkatkan kemandirian dalam pengelolaan hutan rakyat.

Selain daya inovatif petani, sifat kreativitas petani dalam pengelolaan hutan rakyat di Desa Ranggang sangat dibutuhkan untuk menumbuhkan keberanian petani dalam mencoba suatu ide/ gagasan baru dalam pengelolaan hutan rakyat seperti ujicoba budidaya tanaman pakan ternak di bawah tegakan mahoni dan membuat kompos serasah untuk bahan pupuk organik. Subagio (2008) menyebutkan bentuk kreativitas petani yang diperlukan oleh petani dalam usahatani adalah keberanian mencoba ide/gagasan baru sebelum orang lain, memanfaatkan segala peluang yang diraih untuk pengembangan usaha dan setiap perubahan dianggap sebagai sebuah tantangan untuk berkreasi. 


\section{Faktor-faktor yang Berpengaruh terhadap Tingkat Kemampuan Petani}

Terdapat empat faktor yang mempengaruhi tingkat kemampuan petani dalam pengelolaan hutan rakyat di Desa Ranggang yaitu dukungan lingkungan sosial budaya, dukungan pihak luar, kinerja penyuluhan dan dukungan karakteristik petani. Persamaan struktural faktor-faktor yang berpengaruh terhadap kemampuan petani dalam pengelolaan hutan rakyat di Desa Ranggang adalah sebagai berikut:

$\mathrm{X}_{5}=0,219 \mathrm{X}_{1}+0,138 \mathrm{X}_{2}+0,450 \mathrm{X}_{3}+0,208 \mathrm{X}_{4}+\zeta$

$\mathrm{R}^{2}=0,7140$ atau $71,40 \%$

Keterangan (Remarks):

$\mathrm{X}_{5}=$ tingkat kemampuan petani dalam pengelolaan hutan rakyat; $\mathrm{X}_{1}=$ tingkat dukungan lingkungan sosial budaya; $\mathrm{X}_{2}=$ tingkat dukungan pihak luar; $\mathrm{X}_{3}=$ kinerja penyuluhan; $\mathrm{X}_{4}=$ tingkat dukungan karakteristik petani; $\zeta=$ faktor yang mempengaruhi tingkat kemampuan petani selain tingkat dukungan lingkungan sosial budaya, tingkat dukungan pihak luar, kinerja penyuluhan, dan tingkat dukungan karakteristik petani; $\mathrm{R}^{2}=$ besaran pengaruh tingkat kemampuan petani, tingkat dukungan lingkungan sosial budaya, tingkat dukungan pihak luar, kinerja penyuluhan, dan tingkat dukungan karakteristik petani terhadap tingkat kemampuan petani secara bersama-sama.

Hasil analisis SEM (Gambar 1) menunjukkan bahwa faktor kinerja penyuluhan merupakan faktor paling kuat yang mempengaruhi kemampuan petani dalam pengelolaan hutan rakyat di Desa Ranggang. Aspek dalam faktor kinerja penyuluhan yang berpotensi mempengaruhi tingkat kemampuan petani secara berurutan (dari terbesar ke terkecil) adalah aspek kompetensi penyuluh, materi penyuluhan dan metode penyuluhan. Peningkatan kompetensi penyuluh, materi dan metode penyuluhan melalui penguatan kelembagaan penyuluhan dan peningkatan kapasitas penyuluh kehutanan di Desa Ranggang akan memberikan pengaruh positif terhadap kemampuan petani hutan rakyat. Sumarlan et al. (2012) mengemukakan bahwa untuk meningkatkan kemampuan petani diperlukan dukungan kuat dari berbagai pihak terutama penyuluh yang memiliki kapasitas yang tinggi.

Faktor kedua yang berpengaruh kuat terhadap kemampuan petani dalam pengelolaan hutan rakyat di Desa Ranggang adalah dukungan lingkungan sosial budaya. Aspek kelompok tani merupakan salah satu aspek dalam dukungan lingkungan sosial budaya yang berpengaruh paling kuat terhadap kemampuan petani dalam pengelolaan hutan rak- yat di Desa Ranggang. Optimalisasi peran kelompok tani sebagai wahana belajar petani, wahana kerjasama antar petani dan wahana unit usaha bersama merupakan salah satu usaha yang dapat meningkatkan kemampuan petani dalam pengelolaan hutan rakyat.

Dukungan karakteristik petani merupakan faktor ketiga yang berpengaruh terhadap kemampuan petani dalam pengelolaan hutan rakyat di Desa Ranggang. Terdapat tiga aspek yang menjadi tolok ukur dukungan karakteristik petani yaitu pendidikan informal, pengalaman usaha tani dan pendidikan formal. Berdasarkan hasil analisis SEM, pendidikan informal dan pengalaman usahatani memiliki pengaruh paling kuat terhadap peningkatan kemampuan petani dalam pengelolaan hutan rakyat.

\section{Faktor-faktor yang Berpengaruh terhadap Tingkat Kedinamisan}

Beberapa faktor yang berpengaruh terhadap kedinamisan pengelolaan hutan rakyat di Desa Ranggang terdiri dari dukungan lingkungan sosial budaya, kinerja penyuluhan, karakteristik petani, ketersediaan inovasi dan kemampuan petani. Kedinamisan pengelolaan hutan rakyat beserta faktor-faktor yang mempengaruhinya dapat ditulis dalam bentuk persamaan struktural sebagai berikut:

$$
\begin{aligned}
& \mathrm{X}_{6}=0,155 \mathrm{X}_{1}+0,191 \mathrm{X}_{3}+0,101 \mathrm{X}_{4} \\
& +0,408 \mathrm{X}_{5}+0,182 \mathrm{X}_{7}+\zeta \\
& \mathrm{R}^{2}=0,75 \text { atau } 75 \%
\end{aligned}
$$

Keterangan (Remarks):

$\mathrm{X}_{6}=$ tingkat kedinamisan pengelolaan hutan rakyat; $\mathrm{X}_{1}=$ tingkat dukungan lingkungan sosial budaya; $\mathrm{X}_{3}=$ kinerja penyuluhan; $\mathrm{X}_{4}=$ tingkat dukungan karakteristik petani; $\mathrm{X}_{5}=$ tingkat kemampuan petani dalam pengelolaan hutan rakyat; $\mathrm{X}_{7}=$ tingkat ketersediaan inovasi; $\zeta=$ faktor yang mempengaruhi tingkat kedinamisan pengelolaan HR selain tingkat dukungan lingkungan sosial budaya, kinerja penyuluhan, tingkat dukungan karakteristik petani, tingkat kemampuan petani dalam pengelolaan hutan rakyat dan tingkat ketersediaan inovasi; $\mathrm{R}^{2}=$ besaran pengaruh tingkat dukungan lingkungan sosial budaya, kinerja penyuluhan, tingkat dukungan karakteristik petani, tingkat kemampuan petani dalam pengelolaan hutan rakyat dan tingkat ketersediaan inovasi terhadap tingkat kedinamisan pengelolaan hutan rakyat secara bersama-sama.

Hasil analisis SEM (Gambar 1) dan persamaan struktural menunjukkan bahwa faktor terbesar yang berpotensi mempengaruhi kedinamisan pengelolaan hutan rakyat di Desa Ranggang adalah 
kemampuan petani dalam pengelolaan hutan rakyat yang meliputi kemampuan teknis, kemampuan manajerial dan kemampuan sosial. Lebih lanjut hal ini akan berpengaruh terhadap kedinamisan pengelolaan hutan rakyat dalam hal inovasi, kreativitas dan daya saing petani dalam melakukan usahatani hutan rakyat.

Faktor kinerja penyuluhan, ketersediaan inovasi, dukungan lingkungan sosial budaya dan karakteristik petani secara berurutan (terbesar ke terkecil) berpotensi mempengaruhi tingkat kedinamisan pengelolaan hutan rakyat di Desa Ranggang.

\section{Usaha Peningkatan Kemandirian Petani dalam Pengelolaan Hutan Rakyat di Desa Ranggang}

Deskripsi usaha peningkatkan kemandirian petani dalam pengelolaan hutan rakyat di Desa Ranggang dapat dilihat pada Gambar 2.
Berdasarkan hasil analisis SEM (Gambar 1) dan deskripsi hasil analisis (Gambar 2), maka peningkatan kemandirian petani dalam pengelolaan hutan rakyat di Desa Ranggang dapat dilakukan dengan meningkatkan kemampuan dan kedinamisan petani dalam pengelolaan hutan rakyat.

Peningkatan kemampuan teknis, kemampuan manajerial dan kemampuan sosial dapat dicapai dengan mengoptimalkan program pendidikan, pelatihan dan penyuluhan untuk petani hutan rakyat dengan langkah-langkah sebagai berikut:

1. Pengoptimalan peran kelompok tani oleh stakeholders sebagai wahana belajar, wahana kerjasama dan wahana unit usaha bersama untuk para petani hutan rakyat.

2. Peningkatan kinerja penyuluhan oleh institusi penyuluhan (swasta, pemerintah dan LSM) dalam program diklatluh melalui peningkatan ketersediaan inovasi dalam metode dan materi diklatluh serta peningkatan kapasitas penyuluh.

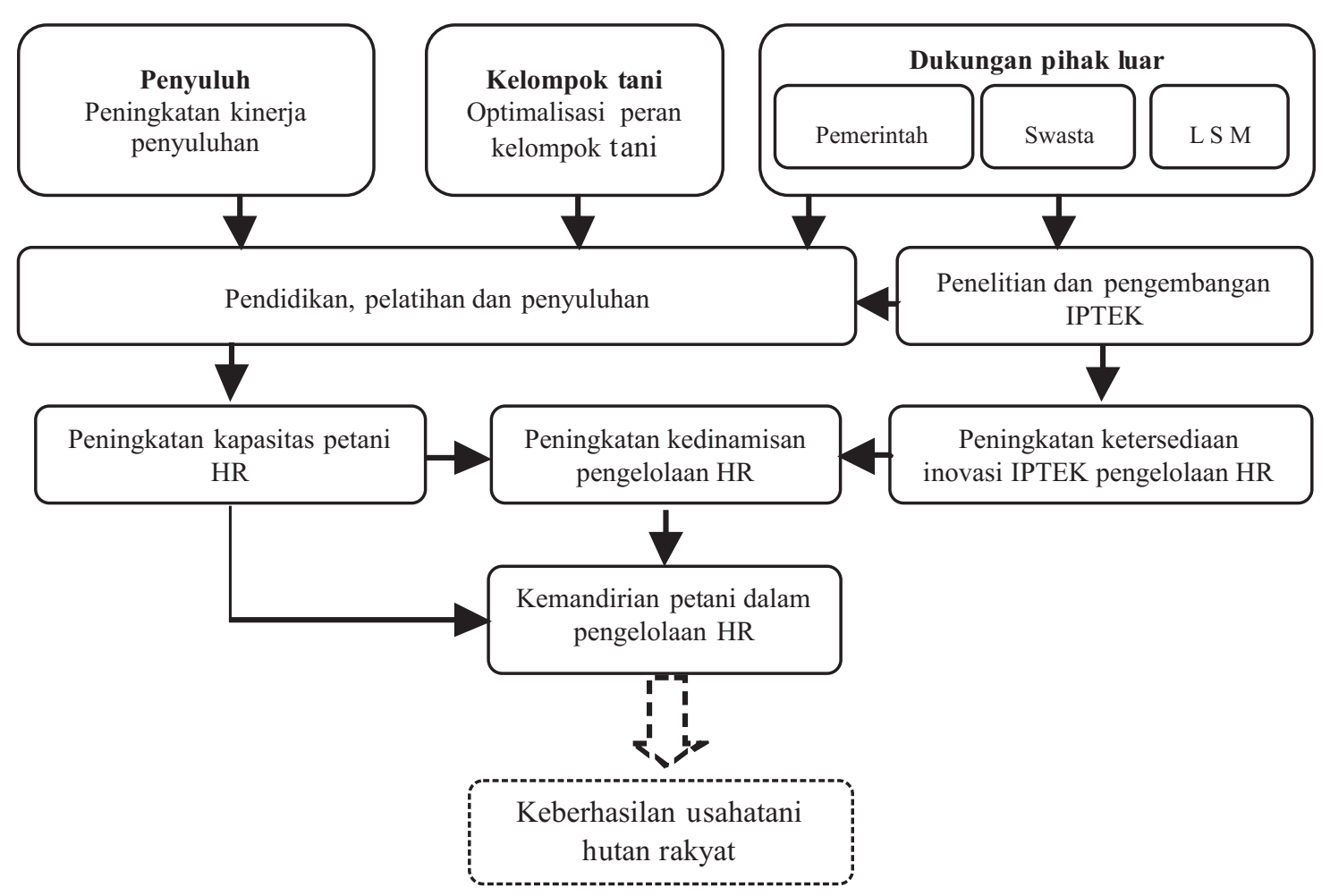

Gambar2. Usaha peningkatan kemandirian petani dalam pengelolaan hutan rakyat di Desa Ranggang, Kabupaten Tanah Laut, Kalimantan Selatan.

Figure 2. Effort to improve farmers self reliance in people forest management in Ranggang village, Tanah Laut District, South Kalimantan. 
3. Pengoptimalan koordinasi dan komunikasi intensif di antara berbagai stakeholders yang berhubungan dengan program diklatuh, seperti antara penyuluh dengan instansi penelitian dan pengembangan milik pemerintah, swasta maupun LSM dalam pemutakhiran inovasi dan informasi mengenai IPTEK dalam pengelolaan hutan rakyat.

4. Pemberian dukungan kebijakan oleh pemerintah daerah dan pemerintah pusat berupa payung hukum, program dan anggaran untuk terlasananya program diklatluh yang berkelanjutan, efektif dan efisien.

Peningkatan kedinamisan petani dalam pengelolaan hutan rakyat dapat dilakukan dengan meningkatkan ketersediaan inovasi dan kemampuan. Peningkatan ketersediaan inovasi pengelolaan hutan rakyat di Desa Ranggang dapat dilakukan dengan cara sebagai berikut:

1. Pemerintah/swasta/LSM melakukan program penelitian dan pengembangan untuk memperoleh inovasi pengelolaan hutan rakyat yang bersifat komprehensif, baik inovasi teknis budidaya tanaman dan inovasi non teknis seperti kelembagaan, sosial dan sebagainya.

2. Peningkatan kemampuan petani (teknis, manajerial dan sosial) dengan mengoptimalkan peran kelompok tani sebagai wahana belajar, wahana kerjasama dan wahana unit usaha bersama dan mengoptimalkan pelaksanaan program pendidikan, pelatihan dan penyuluhan secara efektif, efisien dan berkelanjutan.

\section{KESIMPULAN DAN SARAN}

\section{A. Kesimpulan}

Berdasarkan hasil dan pembahasan yang telah diuraikan, maka diperoleh kesimpulan bahwa kemandirian petani dalam pengelolaan hutan rakyat di Desa Ranggang masih rendah. Hal ini terlihat dari masih rendahnya kemandirian pembinaan, materi dan intelektual yang dimiliki petani dalam pengelolaan hutan rakyat.

Penentu kemandirian petani hutan rakyat di Desa Ranggang terdiri dari kemampuan dan kedinamisan petani dalam pengelolaan hutan rakyat.
Secara umum, kemampuan dan kedinamisan petani dalam pengelolaan hutan rakyat di Desa Ranggang masih rendah. Hal ini tercermin dari rendahnya kemampuan manajerial, kreativitas dan keinovatifan petani dalam pengelolaan hutan rakyat. Penentu tingkat kemandirian tersebut berpengaruh nyata terhadap kemandirian petani dalam pengelolaan hutan rakyat di Desa Ranggang.

Usaha peningkatan kemandirian petani yang dapat dilaksanakan dalam pengelolaan hutan rakyat di Desa Ranggang adalah peningkatan kemampuan dan kedinamisan petani dalam pengelolaan hutan rakyat melalui optimalisasi pelaksanaan program diklatluh secara efektif, efisien dan berkelanjutan serta peningkatkan ketersediaan inovasi teknologi pengelolaan hutan rakyat yang lebih komprehensif, menguntungkan, mudah, sesuai dan dapat diujicoba oleh petani.

\section{B. Saran}

Pemerintah pusat dan daerah disarankan untuk melakukan penguatan kelembagaan diklatluh kehutanan dan peningkatkan kapasitas penyuluh kehutanan di daerah. Selain itu, pemerintah pusat dan daerah disarankan untuk meningkatkan ketersediaan inovasi teknologi dengan cara mendorong institusi penelitian dan pengembangan kehutanan untuk menghasilkan inovasi teknologi pengelolaan hutan rakyat yang dibutuhkan mencakup masalah teknis maupun non teknis.

Pihak swasta dan LSM disarankan untuk memberikan dukungan terhadap peningkatan kemampuan petani dalam bentuk pelatihan, pendidikan, pendampingan maupun penyediaan inovasi teknologi untuk petani dalam pengelolaan hutan rakyat.

\section{UCAPAN TERIMA KASIH}

Penulis mengucapkan terima kasih kepada Bapak Suripto dan Bapak Supriyanto (Ketua dan Sekretaris Kelompok Tani Desa Ranggang), Sopian Agus, Dian Cahyo Buono dan Abdul Kodir (Balai Penelitian Kehutanan Banjarbaru) serta para pihak lain yang telah memberikan perhatian, bantuan pengumpulan data dan kerjasamanya. 


\section{DAFTAR PUSTAKA}

Anantanyu. (2008). Tipe petani dan strategi pengembangan kelembagaan kelompok petani (Kasus di Provinsi Jawa Tengah). Jurnal Penelitian M Power, 8(8), 34-48.

Anonim. (2010). Profil Desa Ranggang Kecamatan Takisung Kabupaten Tanah Laut Tabun 2010. Tanah Laut: Pemerintah Desa Ranggang.

Badan Pusat Statistik. (2009). Takisung dalam angka. Tanah Laut: Badan Pusat Statistik Kabupaten Tanah Laut.

Ediningtyas, D. (2007). Kemandirian masyarakat desa sekitar hutan dalam melakukan usaha agroforestry: Studi kasus usahatani agroforestry tanaman kopi di BPKH Pangalengan, KPH Bandung Selatan, Perum Perbutani Unit III, Jawa Barat Banten. (Tesis). Program Studi Ilmu Penyuluhan Pembangunan, Sekolah Pascasarjana Institut Pertanian Bogor, Bogor.

Indraningsih, K.S. (2013). Faktor-faktor yang mempengaruhi kinerja usahatani petani sebagai representasi strategi penyuluhan pertanian berkelanjutan di lahan marjinal. Jurnal Agroekonomi, 31(1), 71-95.

Mindawati, N., Widiarti, A., \& Rustaman, B. (2006). Review hasil penelitian butan rakyat. Bogor : Pusat Penelitian dan Pengembangan Hutan Tanaman.

Mulyandari, R.S.H. (2001). Faktor-faktor yang mempengarubi pengembangan kemandirian petani melalui penyuluban: Studi di Desa Ciherang, Kacamatan Dramaga, Kabupaten Bogor, Jawa Barat. (Tesis). Program Studi Ilmu Penyuluhan Pembangunan, Sekolah Pascasarjana Institut Pertanian Bogor, Bogor.

Mun'im, A. (2012). Analisis faktor ketersediaan, akses dan penyerapan pangan di kabupaten surplus pangan: Pendekatan Partial Least Square Path Modelling. Jurnal Agroekonomi, 30(1), 41-56.

Riduan. (2007). Cara menggunakan dan memaknai analisisjalur. Bandung: Alfabeta.
Rohadi, D. (2012). Analisis persepsi dan strategi petani dalam usaha tanaman kayu rakyat: Studi kasus usaba tanaman kayu rakyat di Kabupaten Gunung Kidul Daerah Istimewa Yogyakarta dan Kabupaten Tanah Laut, Provinsi Kalimantan Selatan. (Disertasi). Program Studi Ilmu Pengetahuan Kehutanan, Sekolah Pascasarjana Institut Pertanian Bogor, Bogor.

Ruhimat, I.S. (2010). Kajian sosiologis kelembagaan hutan rakyat: Studi kasus tata nilai masyarakat dalam pengelolaan hutan rakyat di Desa Ranggang, Kabupaten Tanah Laut, Kalimantan Selatan (pp 365-370). In T. Rostiwati, Nurhasybi, L. Baskorowati, Y. Mile, \& B. Achmad (Eds.), Prosiding Seminar Hasil-Hasil Penelitian BPTP Bogor dan BPK Ciamis. Bandung: Puslitbang Peningkatan Produktivitas Hutan.

Ruhimat, I.S. (2011). Kajian model pengembangan hutan rakyat di Kabupaten Tanah Laut: Studi di Desa Ranggang, Kecamatan Takisung, Kabupaten Tanah Laut (pp. 371-378). In Arifin, Y.F., Savitri, E., \& Akbar, A. (Eds.), Prosiding Ekespose Hasil Penelitian BPK Banjarbaru Tahun 2011. Banjarmasin: Puslitbang Peningkatan Produktivitas Hutan.

Santoso, S. (2012). Analisis SEM menggunakan AMOS. Jakarta: Elex Media Komputindo.

Sarwono, J. (2012). Path analysis: Teori, aplikasi, prosedur analisis untuk riset skripsi, tesis, disertasi dengan menggunakan SPSS. Jakarta: PT Elex Media Komputindo

Subagio, H. (2008). Peran kapasitas petani dalam mewujudkan keberbasilan usahatani: Kasus petani sayuran dan padi di Kabupaten Malang dan Pasuruan, Provinsi Jawa Timur. (Disertasi). Departemen Komunikasi dan Pengembangan Masyarakat, Sekolah Pascasarjana Institut Pertanian Bogor, Bogor.

Sumarlan, Sumardjo, Prabowo, T., \& Darwis, S. (2012). Peningkatan kinerja petani sekitar hutan dalam penerapan sistem agroforestry di pegunungan Kendeng Pati. Jurnal Agroekonomi, 30(1), 25-39. 
Suprayitno, A., Sumardjo, Darwis, S., \& Basita, G. (2011). Model peningkatan partisipasi petani sekitar hutan dalam mengelola hutan kemiri rakyat: Kasus pengelolaan hutan kemiri kawasan pegunungan Bulusaruang, Kabupaten Maros, Sulawesi Selatan. Jurnal Penelitian Sosial Ekonomi Kebutanan, 8(3), 176195.
Wiyono, G. (2011). Merancang penelitian bisnis dengan SPSS dan SmartPLS 2.0. Yogyakarta: Unit Penerbit dan Percetakan STIM YKPN.

Zulkarnain, E. (2008). Analisis tingkat keberhasilan butan rakyat dan strategi pembangunan butan rakyat di Kabupaten Purwakarta. (Tesis). Program Studi Manajemen Pembangunan Daerah, Sekolah Pascasarjana Institut Pertanian Bogor, Bogor. 